\title{
Blooming Pattern of Passion Fruit Flower (Passiflora edulis Sims.) Under Diversified Flashes
}

\author{
${ }^{1}$ Das, M.R., ${ }^{2}$ T. Hossain, ${ }^{2}$ M.A. Baset Mia, \\ ${ }^{2}$ J.U. Ahmed, ${ }^{3}$ A.J.M. Sirajul Karim and ${ }^{4}$ M.M. Hossain \\ ${ }^{1}$ Department of Agricultural Extension, Agriculture Training Institute, Gazipur, Bangladesh \\ ${ }^{2}$ Department of Crop Botany, \\ ${ }^{3}$ Department of Soil Science, \\ ${ }^{4}$ Department of Horticulture, \\ Faculty of Agriculture, Bangabandhu Sheikh Mujibur Rahman Agricultural University, Gazipur, Bangladesh
}

Received 2013-01-10; Revised 2013-01-28; Accepted 2013-07-26

\begin{abstract}
Passion fruit has great potential to attract for its lucrative flavor, taste and deliciousness to grown up the economic condition of the framer in the developing country. Study of flower blooming can play vital role in developing high yielding varieties of this fruit. Filed and laboratory experiments were conducted at the Bangabandhu Sheikh Mujibur Rahman Agricultural University, Gazipur, Bangladesh to determine the flowering behavior of yellow passion fruits (Passiflora edulis Sims.) at five flashes. The results revealed that third flash showed the best performance in respect of all floral biological attribute namely floral primodia initiation, period of flower bud formation to blooming, flowering duration, number of floral bud, number of flower bloomed, percent flowers opened, flowering interval, bud size, initiation, completion and withering of floral parts. Thus, the results may be concluded that third flash would the best for better fruit production.
\end{abstract}

Keywords: Passion Fruit, Flash, Flowering Behavior, Flowering Interval, Withering

\section{INTRODUCTION}

Passion fruit (Passiflora edulis Sims.) belongs to the family Passifloraceae with the basic number of chromosomes $\mathrm{n}=9(2 \mathrm{n}=18)$. Passiflora genus contains more than 450 species but 12 species are being cultivated. Only single species Passiflora edulis Sims. is highly commercialized for its quality fruit production (Kole, 2011). Due to its rapid production rates in comparison with other fruits and its demand in the market, both for fresh consumption and industrial processing sour passion fruit (Passiflora edulis Sims) is of great interest to fruit producers (Madureira et al., 2012). There are two recognized forms of edible passion fruit-purple and yellow. The yellow passion fruit (Passiflora edulis Sims) is widely cultivated in Brazil and its fruits are consumed fresh.
The passion flower is native to Brazil, widely cultivated in frost free area including India, Sri Lanka (Shivanna, 2012; Kishore et al., 2010). It is largely distributed around the tropics and humid subtropics. The species of the Passiflora genus are widely distributed in tropical and subtropical regions (Silva et al., 2009) where the solar radiation is high, humid and shaded environment are present. It is cultivated for its ornamental, medicinal and nutritive characteristics (Shivanna, 2012). The fruit is gaining prominence for its excellent taste and flavor for the diverse group of people in the world. It is an excellent fruit having high amount of beta carotene, potassium and dietary fiber (Gahakwa et al., 2012). The flower of passion fruit has a mild sedative and can help to induce sleep. Passion flower has been used in the treatment of nervous and easily excited children bronchial asthma, insomnia,

Corresponding Author: Das, M.R., Department of Agricultural Extension, Agriculture Training Institute, Gazipur, Bangladesh 
nervous gastrointestinal disorders and menopausal problems. Passion flower is sometimes used as a mild hallucinogen, reduction of asthma symptoms. Yellow passion fruit extracts can kill cancer cells. The phytochemicals responsible for these anti-cancer effects are carotenoids and polyphenols (Patel et al., 2009). It is also known as parcha, granadilla, maracuyá, ceibey, lilikoi and linmangkon (Joy, 2010). In Bangladesh, passion flower is known as 'humkalota' and considering taste, flavour and colour with tang-juice the passion fruit is also called a 'tangfal' (Ullah et al., 2009).

Passion fruit is a woody perennial vine crop (Banu et al., 2009) is an allogamous plant mainly due to its floral morphology and self-incompatibility of sporophytic type (Souza et al., 2010) being cultivated for its edible fruits.

Passion fruit has hermaphrodite, solitary flowers, located in the leaf axils having five stamens and the ovary is borne over the androgynophore. There are three styles united at base and at the top of style there are three bifurcated stigmas (Matthews and Endress, 2008). It is protandrous as anther dehiscence before stigma becomes receptive which persists from time of flower blooming to withering. The style of passion flowers shows rhythmic movement which is in upright position and it starts curving in course of time resulting expression of selfincompatibility. The self-incompatibility is an important factor for fruit production (Souza et al., 2010).

In some areas, passion fruit plants produce flower and fruit twice a year, plants usually begin blooming and fruiting in the second year. It grows well in hot and moist climatic conditions. It is a special type of flower and blooming pattern is rather different from other alien fruit crop of Bangladesh. Banu et al. (2009) reported flowering of passion fruit from April to September in hilly regions of Bangladesh. They also reported variation in time for two accessions of passion fruit. Kishore et al. (2010) recorded the maximum duration of bloom and duration of effective bloom of $P$. foetida during MarchApril at Mizoram of India when mean temperature, relative humidity and annual rainfall were $28.5^{\circ} \mathrm{C}, 71.2 \%$ and $2650 \mathrm{~mm}$, respectively. It is a long day plant and day length require more than $10.5 \mathrm{~h}$ (Ullah et al., 2009). Flower blooming of passion flowers were reported variable by Kishore et al. (2010) Passiflora species have flowering behavior varying among the year and consequently with variation in fruit production and harvesting time (Ataide et al., 2012). Detailed information regarding the flowering behavior of passion fruit is not available which is important for breeding aspect for increasing fruit set. With this view in mind an experiment was conducted to study the flowering pattern of passion fruit throughout the year under varied flashes.

\section{MATERIALS AND METHODS}

The experiment was conducted at the experimental farm of the Bangabandhu Sheikh Mujibur Rahman Agricultural University, Gazipur, Bangladesh where the climate is characterized by heavy rainfall. The soil of the experimental field was clay loam in texture and acidic in nature having $\mathrm{pH}$ 5.8. The experimental plot was welldrained high land where vine cuttings were transplanted in pits $\left(50 \times 50 \times 50 \mathrm{~cm}^{3}\right)$.

The yellow passion fruit (Passiflora edulis Sims.) was used as test material for the experiment and vine cuttings were transplanted in the pits where the pit to pit distances were $2.5 \mathrm{~m}$. Trellises required for the production of passion fruit for the life of the vine and a single row trellises system was used. The spacing of the passion fruit directly related to the spacing of the poles of the trellis and vines were pruned in late winter, irrigation and management practices were done as and when necessary. Yellow passion fruit vines begin flowering in the April-May, usually peaking in midAugust and continuing until October or November. Data on flower bud initiation, duration of flower bud initiation, days required from bud initiation to flower blooming were recorded. Other flowering attributes namely, duration at different flashes, flower buds per plant, percent of flowers bloomed, bud size, flowering initiation and completion, withering of floral parts were recorded. These parameters were computed from mean of two consecutive years (2008 and 2009) of 30 flowers. The collected data were analyzed statistically using MSTAT-C computer package (Michigan State University, East Lansing, MI, USA) following the methods of Gomez and Gomez (1984) and Kishore et al. (2010). The Analysis of Variance procedure (ANOVA), differences among treatment means were determined using the Least Significant Difference (LSD) at 5\% level of significance.

\section{RESULTS}

\subsection{Floral Primordial Initiation}

Passion fruit produces solitary flower bud at the axils of leaf. Flower bud is a reproductive organ of passion fruit from which flower is developed. Floral primodia initiation started in April (Table 1). It showed first bud flash in April 10, second in May 09, third in June 15, fourth in July 02 and finally fifth in August 03. It is assumed that flowering period and numbers of flashes are affected by climatic condition as well as geographic position of cultivation. Weather data has been shown in Fig. 1-4. 
Das, M.R. et al. / American Journal of Agricultural and Biological Sciences 8 (3): 173-181, 2013

Table 1. Flower primodia initiation and days required for flower bud initiation at different flashes (2008 and 2009)

\begin{tabular}{llll}
\hline Flashes & $\begin{array}{l}\text { Date of floral } \\
\text { primodia initiation }\end{array}$ & $\begin{array}{l}\text { Duration of flower } \\
\text { bud initiation (days) }\end{array}$ & $\begin{array}{l}\text { Days required from bud } \\
\text { initiation to flower blooming }\end{array}$ \\
\hline First & April 10 & $11 \pm 0.48$ & $15 \pm 0.55$ \\
Second & May 09 & $14 \pm 0.41$ & $13 \pm 0.24$ \\
Third & June 05 & $15 \pm 0.44$ & $10 \pm 0.45$ \\
Fourth & July 02 & $13 \pm 0.23$ & $12 \pm 0.24$ \\
Fifth & August 03 & $10 \pm 0.33$ & $14 \pm 0.20$ \\
\hline
\end{tabular}

*Values are mean of two consecutive years (2008 and 2009) of 30 flowers

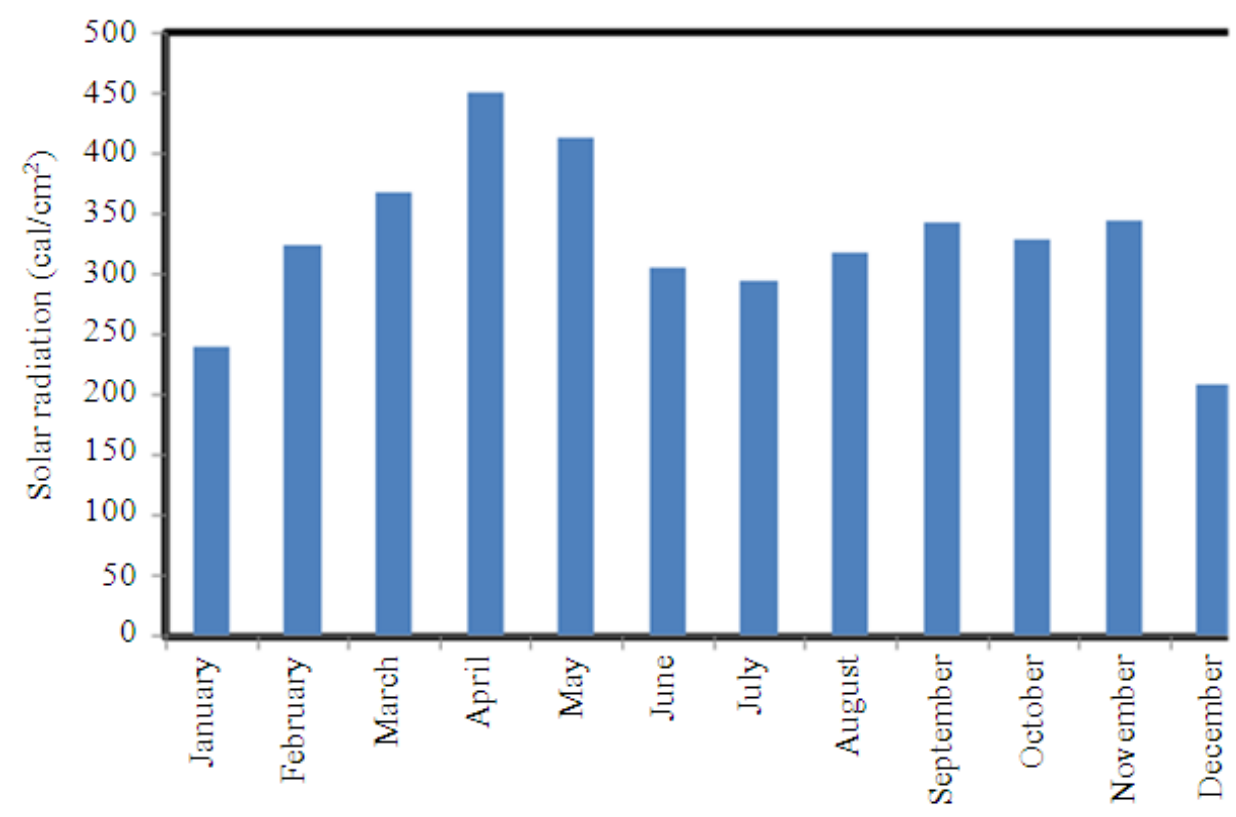

Months (2008)

Fig. 1. Solar radiation during the experimental period (2008)

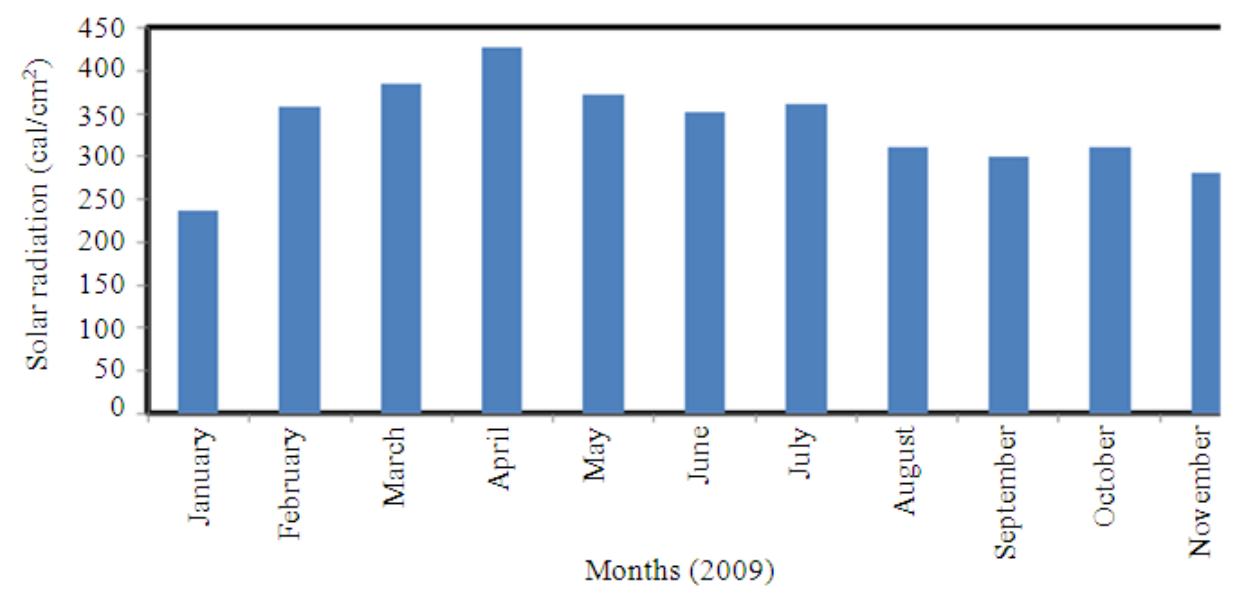

Fig. 2. Solar radiation during the experimental period (2009) 


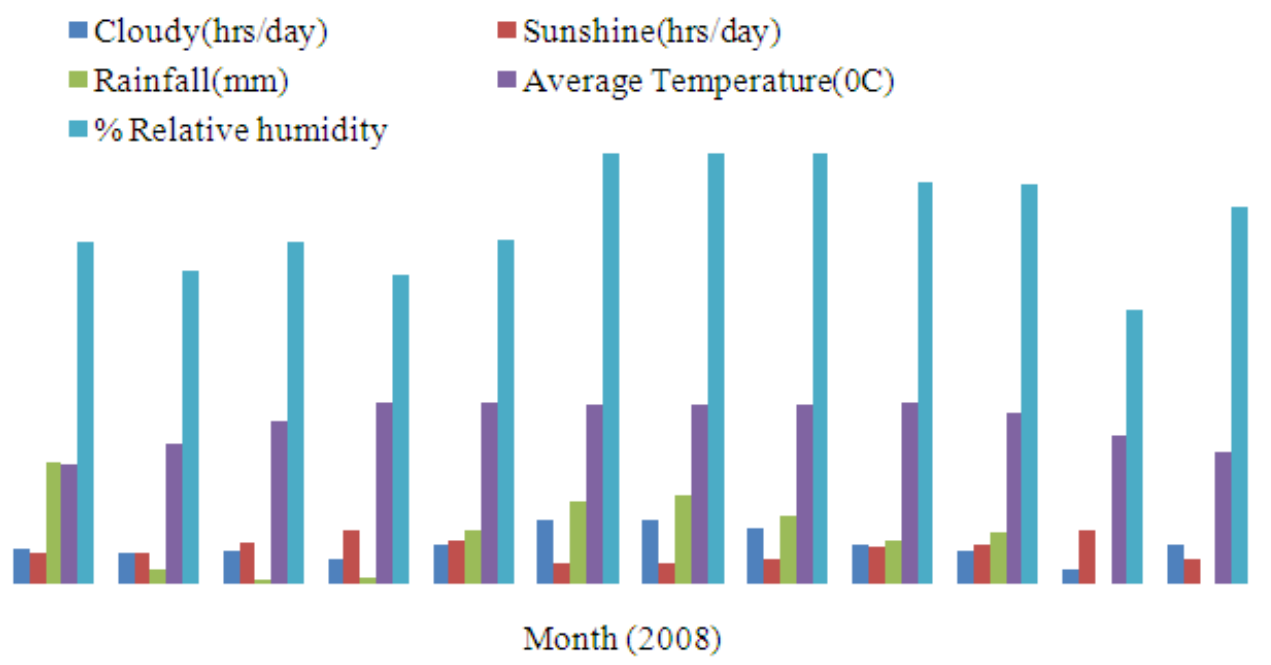

Fig. 3. Meteriological parameters of the experimental period (2008)

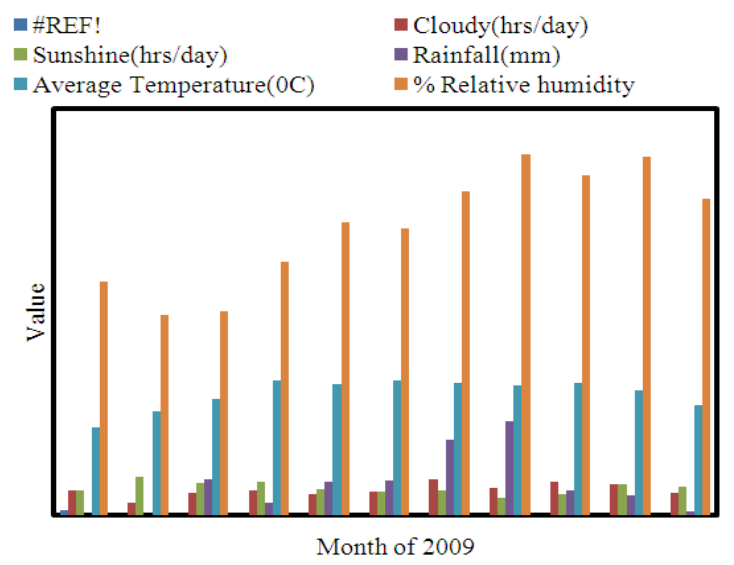

Fig. 4. Meteriological parameters of the experimental period (2009)

\subsection{Duration of Flower Bud Initiation}

Duration of bud formation at different flashes was noticed variable (Table 1). The duration of flower bud formation ranged from 10 to 15 days at different flashes. The third flash requires the longest duration of bud formation and fifth flash took the shortest. Passion fruit showed luxuriant growth from May to July (data not showed). Duration of flower bud formation is assumed to be associated with plant vigor and weather conditions.

\subsection{Days Required from Bud Formation to Flower Blooming}

Days required from bud initiation to flower blooming of passion fruit varied among the flashes
(Table 1). Days ranged from 10 to 15 at different flashes for flower blooming. At first flash, 15 days were required to open flower. The requirement of days from bud initiation to flower opening was recorded to be decreased with the advancement of plant age. At third flash only 10 days were required to open the flower after bud initiation. At fourth and fifth flashes it required 12 and 14 days, respectively from bud initiation.

\subsection{Flowering Duration at Different Flashes}

Flowering duration of passion fruit at different flashes was varied among the flashes (Fig. 5). The longest duration of flowering was recorded at third flash and the duration at other flashes was noticed to be declined.

\subsection{Flower Buds per Plant}

Number of flower buds per plant varied from first to fifth flash (Table 2). These numbers ranged from 85 to 232 at different flashes. Plant produced the lowest number of flower buds at fifth flash in a year. Buds per plant were recorded the highest at third flash. Time requirement was noticed very short from commencement of blooming to full bloom.

\subsection{Number of Flowers Bloomed}

Plant showed maximum blooming of flower at third flash during the month of June (Table 2). In fifth flash drastic reduction in number of flowers was observed in fifth flash in August. 
Das, M.R. et al. / American Journal of Agricultural and Biological Sciences 8 (3): 173-181, 2013

Table 2. Production of flower buds and blooming of flowers at different flashes of passion fruit

\begin{tabular}{llll}
\hline Flashes & $\begin{array}{l}\text { Flower buds } \\
\text { per plant }\end{array}$ & $\begin{array}{l}\text { Flowers opened from } \\
\text { flower buds per plant }\end{array}$ & $\begin{array}{l}\text { Percent of flowers } \\
\text { open per plant }\end{array}$ \\
\hline First & $133 \pm 0.88$ & $52 \pm 0.68$ & $39.10 \pm 0.29$ \\
Second & $219 \pm 0.86$ & $125 \pm 0.71$ & $57.08 \pm 0.29$ \\
Third & $232 \pm 0.78$ & $146 \pm 0.67$ & $62.93 \pm 0.25$ \\
Fourth & $200 \pm 0.99$ & $105 \pm 0.65$ & $52.25 \pm 0.29$ \\
Fifth & $85 \pm 0.65$ & $27 \pm 0.65$ & $31.76 \pm 0.25$ \\
Mean & 173.80 & 91.00 & 48.62 \\
\hline
\end{tabular}

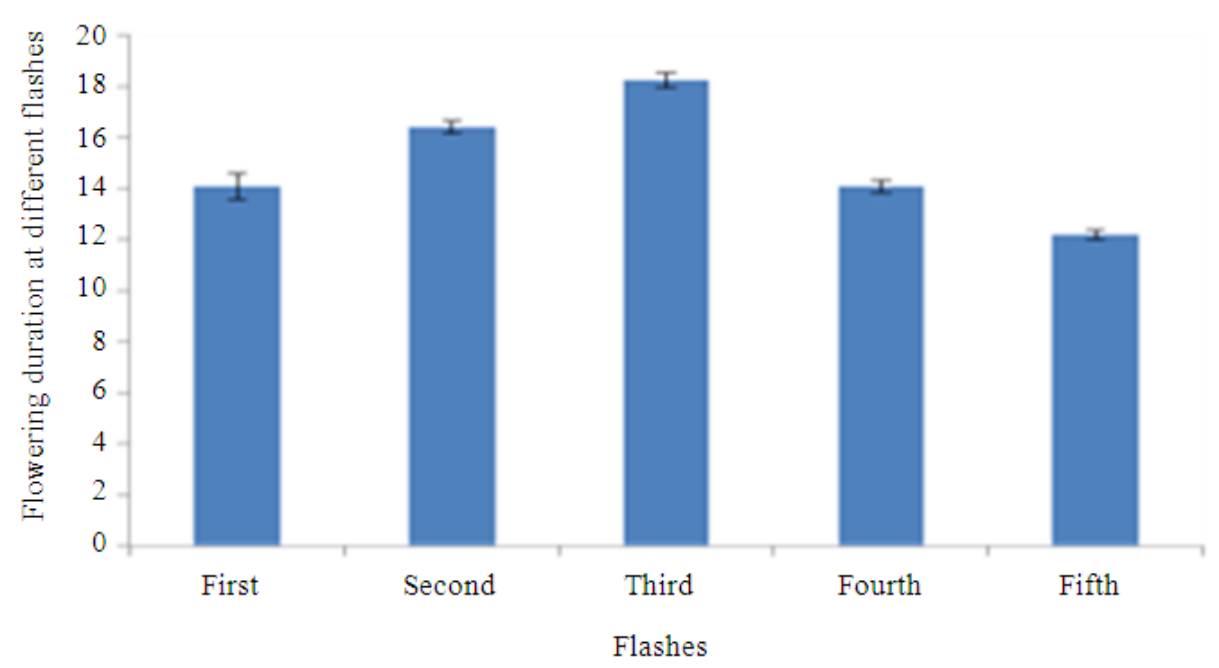

Fig. 5. Flowering duration of passion fruit under different flashes

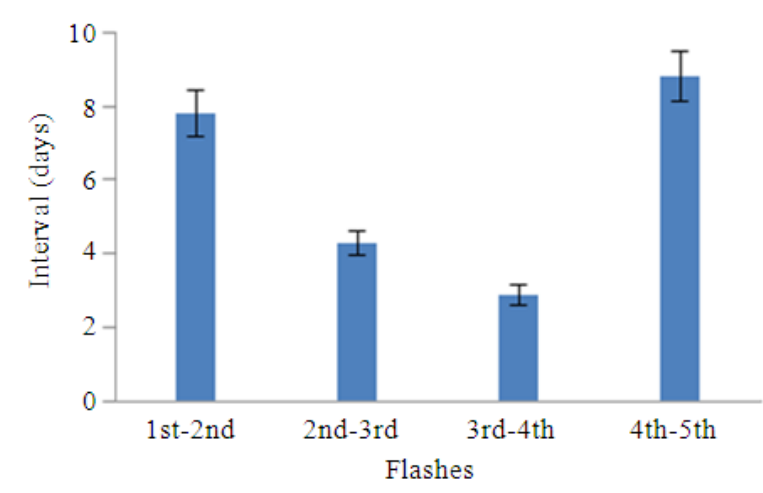

Fig. 6. Flowering intervals of different flashes of passion fruit

\subsection{Percent of Flowers Opened}

Flowering of a plant is associated with growth, development and prevailing environmental conditions (Table 2). At different flashes, percent of flowers per plant was recorded variable in number. Plant produced the highest percent of flowers at third flash in June. Flowering percent ranged from 31.76 to 62.93 . The flowering percent from first flash to third flash increased gradually with the advancement of plant age. On the other hand, with the further advancement of plant age a reverse trend was noticed.

\subsection{Flowering Interval}

Flowering intervals among different flashes ranged from 2.9 to 8.8 days (Fig. 6). This interval was recorded the longest ( 8.8 days) between fourth and fifth flashes followed by first and second, second and third and third and fourth flashes. The shortest interval (2.9 days) was noticed between third and fourth flashes. Passion fruit showed luxuriant growth in humid weather associated with high temperature (Fig. 3 and 4). Plants showed the shortest flowering interval during humid weather prevailing high temperature.

\subsection{Bud Size}

Bud size of passion fruit at different flashes ranged from 6.70 to $8.10 \mathrm{~cm}$ (Table 3). Bud size of passion fruit was recorded minimum at first flash. Compared with other flashes plant produced the largest buds $(8.10$ 
$\mathrm{cm}$ ) and at third flash bud size was noted smaller. At third flash, passion fruit produced $12.19 \%$ larger bud compared with mean bud size. Similarly, fresh weight of each bud on previous day of flowering at different flashes varied. Fresh weight of bud was noted the largest at fourth flash. As other parameters plant produced the largest bud at third and fourth flashes.

\subsection{Flower Initiation and Completion}

Flowering initiation and completion of passion fruit at different flashes were presented in Table 4. At different flashes flowering initiation time ranged from 09:05 am to 11:10 am. Flowering initiation was recorded earlier at third flash. Before and after third flash flowering initiation was noticed to delay. At first flash flowering was recorded to delay. On the other hand, following completion ranged from 15:45 pm to 18:25 $\mathrm{pm}$ at different flashes. Among the five flashes flowering completion was noted earlier at third flash. Passion fruit requires high temperature and humidity for flowering which reviled during third flash in the present experiment. Temperature and humidity of experimental area has been shown Fig. 3 and 4. Total flowering time among different flashes ranged from 6 h $10 \mathrm{~min}$ to $7 \mathrm{~h} 15 \mathrm{~min}$ (Table 4).
Flowering pattern of passion fruit at different flashes was presented in Fig. 7. Flowering pattern of passion fruit at different flashes was observed variable. Flowering period at different flashes ranged from 09:00 am to 17:00 pm during crop year. At first flash flowering started at 11:00 am and continued up to $16: 00 \mathrm{pm}$. With the advancement of plant age flowering was noticed to start earlier up to third flash, but with the further advancement of plant age flowering was noticed to delay. Among the five flashes plant produced flower earliest $(09: 00 \mathrm{am})$ at first flash and completed flowering earliest (at 15:00 pm). At all flashes plants showed maximum blower between 12:00 and 13:00 pm. Plants produced the highest percent (35) of flowers at 12:00 noon at third flash. In the present experiment mid-day (12:00 13:00 hr) was noticed to be the best time for flowering of passion fruit. Plant produced $50 \sim 60 \%$ flowers at this period at 5 flashes.

Withering is the terminal phase of developmental processes which includes flower wilting, shedding of flower parts and fading of blossoms. Withering of floral parts is a rapid process as compared to senescence of other plant parts.

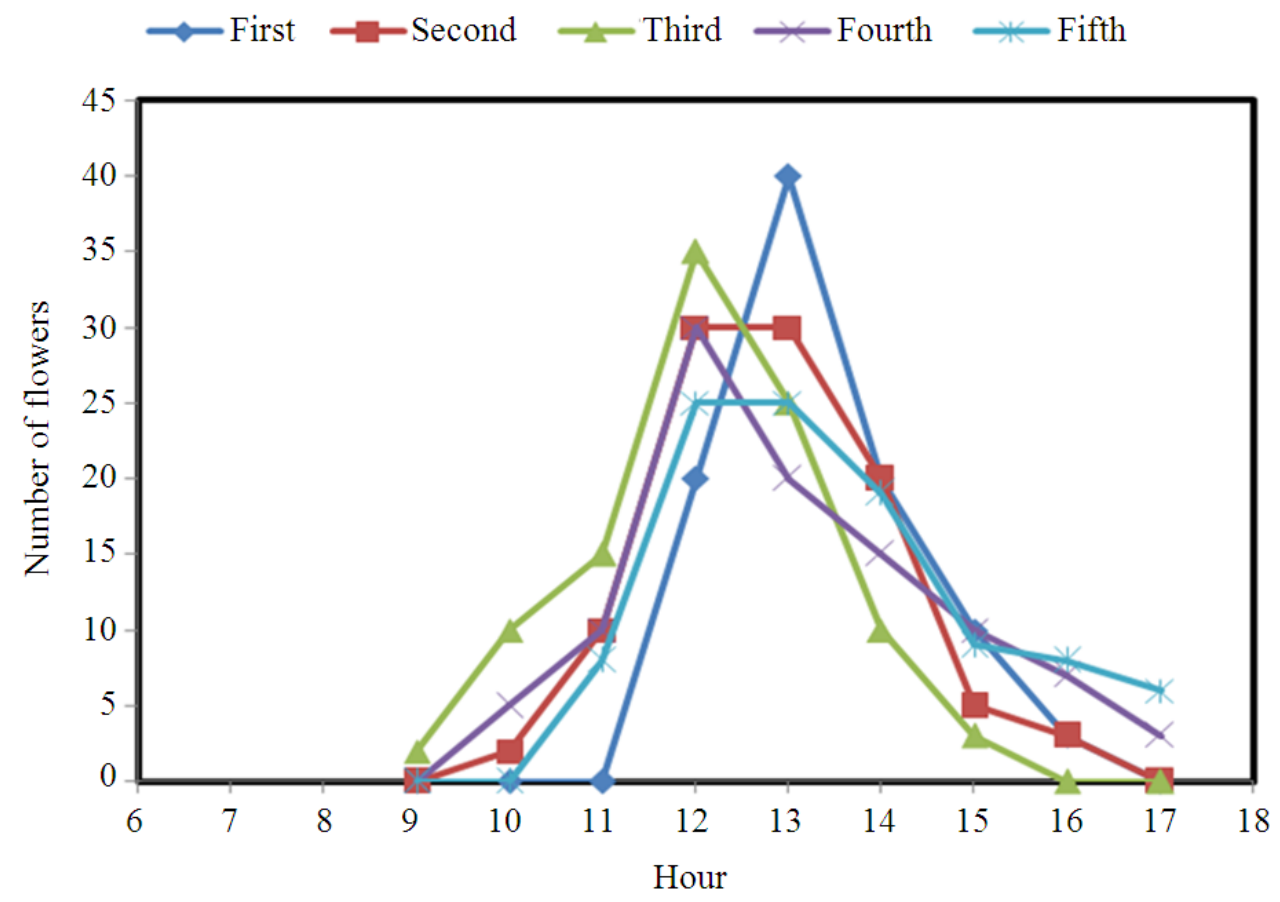

Fig. 7. Passion flowers bloomed at different flashes 
Das, M.R. et al. / American Journal of Agricultural and Biological Sciences 8 (3): 173-181, 2013

Table 3. Bud size at different flashes of passion fruit on previous day before flowering

\begin{tabular}{llclr}
\hline Flashes & Bud length $(\mathrm{cm})$ & Change Over mean & Fresh weight $(\mathrm{g})$ & Change Over mean \\
\hline First & 6.70 & -7.22 & 2.84 & -7.49 \\
Second & 6.80 & -5.82 & 2.88 & -6.19 \\
Third & 8.10 & +12.19 & 3.26 & +6.19 \\
Fourth & 7.40 & +4.49 & 3.58 & +16.61 \\
Fifth & 7.10 & -1.66 & 2.79 & -9.12 \\
Mean & 7.22 & - & 3.07 & - \\
\hline
\end{tabular}

Table 4. Flowering time of passion fruit at different flashes (hours) in a day

\begin{tabular}{|c|c|c|c|}
\hline \multirow[b]{2}{*}{ Flashes } & \multicolumn{3}{|c|}{ Flowering time (hours of a day) } \\
\hline & Initiation & Completion & Total flowering time hrs) \\
\hline First & $11: 10$ & 18.25 & $7 \mathrm{~h} 15 \mathrm{~min}$ \\
\hline Second & $10: 25$ & $16: 35$ & $6 \mathrm{~h} 10 \mathrm{~min}$ \\
\hline Third & 09:05 & $15: 45$ & $6 \mathrm{~h} 40 \mathrm{~min}$ \\
\hline Fourth & 09:50 & $16: 05$ & $6 \mathrm{~h} 15 \mathrm{~min}$ \\
\hline Fifth & $10: 30$ & $16: 50$ & $6 \mathrm{~h} 20 \mathrm{~min}$ \\
\hline
\end{tabular}

Table 5. Time of initiation of withering of floral parts of passion fruit after full bloom (in hours) at different flashes

\begin{tabular}{|c|c|c|c|c|}
\hline \multirow{2}{*}{$\begin{array}{l}\text { Different } \\
\text { Flashes }\end{array}$} & \multicolumn{4}{|c|}{ Different floral parts } \\
\hline & Sepal & Petal & Stamen & Carpel \\
\hline First & 16.00 & 8.30 & 6.15 & 8.00 \\
\hline Second & 17.00 & 8.00 & 6.25 & 9.00 \\
\hline Third & 19.30 & 8.00 & 7.00 & 10.00 \\
\hline Fourth & 18.25 & 8.00 & 6.30 & 8.25 \\
\hline Fifth & 15.30 & 8.15 & 6.00 & 8.30 \\
\hline
\end{tabular}

*Mean findings of 15 flowers

Withering of different floral parts at different flashes of passion flower initiated at different time after full bloom (Table 5). Among the floral parts, stamens started withering earliest. On the other hand among the flashes stamens of flowers of third flash were noticed to be withered with delay. Similar tendency of withering of carpels were noted, though the initiation of withering of carpel was recorded with some delay than stamen. Between the accessory organs of passion fruit flower, petal showed initiation of withering quite earlier than sepal. Among the flashes, sepal of flower of third flash was recorded to be delayed which may contribute for the growth of ovary into fruit as the ventral part of sepal is green in color.

\section{DISCUSSION}

Generally passion fruit showed flower blooming during April to August when the temperature and humidity are high. In the experimental location, during
April to August the weather parameters showed higher values than rest of the months. In Bangladesh passion fruit blooms flowering during this period. The findings of Kishore et al. (2010) are similar with the present study that maximum flower blooming occurred during March to June. Flowering behavior is an important criterion for plant breeder in variety development. Kishore et al. (2010) reported that purple, giant and $P$. foetida had major bloom during March-April, July-August and September-October at Mizoram, India during 2005-2007. They also reported the minimum bloom period and effective bloom period in purple, giant and $P$. foetidaa during January-February. It is assumed that flowering period and numbers of flashes are affected by climatic condition as well as geographic position of cultivation. In another study, Banu et al. (2009) mentioned that days from flower bud to full bloom in case of plants grown from cutting required 14 days, but in case of plants grown from seeds required 13 days. Time required from bud initiation to flower opening ranged from 10.00 to15.00 days at different flashes in the present study which are supported by Banu et al. (2009). The highest frequency of flower blooming during $11 \mathrm{am}$ to $1.00 \mathrm{pm}$ might be due to higher solar radiation and temperature accompanied with high humidity (Fig. 1-4). Maximum photosynthesis and diurnal respiration accelerated the phenomena.

Kishore et al. (2010) reported that different species of cultivated Passiflora spp. respond differently to environmental factors. The radiation of the sun, which can be characterized by its quality, duration and intensity are a basic factor for plant development and 
flower production (Santos et al., 2012). The irradiance of the environment in which the plants grow is of fundamental importance, because the adaptation of the plants to this environment depends on the adjustment of their photosynthetic apparatus, so the light is used in a possibly more efficient way (Santos et al., 2012). High irradiance may reduce the productivity of tropical plants (Santos et al., 2012). The duration of flower bud formation in the present study was recorded the longest at third flash (June) which was associated with the vigor of plant and weather condition.

Joy (2010) observed that the influence of seasonality on the physical characteristics of the yellow passion fruit (Passiflora edulis f. flavicarpa) was significantly better in moderate temperature (October to December $1995)$ and rainfall.

Santos et al. (2012) reported that photoperiod, air temperature and soil moisture determines the yield of yellow passion fruit (Passiflora edulis f. flavicarpa Sims.). The flowering, the fructification and the yield were not significantly affected by the different times of lighting.

Similar findings regarding floral withering of parts were reported by Lambers et al. (2008) who explained that during withering, developmental and environmental stimuli enhance the upregulation of catabolic processes causing breakdown and mobilization of cellular components.

\section{CONCLUSION}

The results indicated that duration of bud formation at different flashes was noticed variable and the longest duration was required under third flashing condition. Similarly, days required from bud initiation to flower blooming varied from 10 to 15 at different flashes. At third flash only 10 days were required to open flower form bud initiation. Plants produced maximum number of flowers per plant during third flash in June from the total buds. Flowering interval among different flashes were recorded variable. The shorted interval (3 days) was noticed between third and fourth flashes. Passion fruit produced largest size of buds at third and fourth flashes. Flowering initiation (blooming) during third flash was recorded at 09:05 $\mathrm{h}$ which was earlier than other flashes. Flowering percent at 12:00 was observed the highest (35\%) during third flash followed by second and fourth flashes. Withering of sepals was noted to be delayed during third flash which positively contributed to ovary development and fruit setting.

\section{REFERENCES}

Ataide, E.M., J.C.D. Oliveira, and C. Ruggiero, 2012. Flowering and fructification of wild passion fruit Passiflora setacea D. C. grown in Jaboticabal, SP. SP. Rev. Bras. Frutic, 34: 377-381. DOI: 10.1590/S0100-29452012000200009

Banu, M.B., M.Q.I. Matin, T. Hossain and M.M. Hoassain, 2009. Flowering behaviour and flower morphology of passion fruit (Passiflora edulis Sims). Int. J. Sustain. Crop Prod., 4: 05-07.

Gahakwa, D., T. Asiimwe, N. Senkensha, J. Kajuga and P. Rukundo et al., 2012. Biotechnology for improving food security in Rwanda. Rwanda J. DOI: 10.4314/rj.v28i1.8

Gomez, M.A. and A.A. Gomez, 1984. Statistical Procedures for Agriculture Research. 2nd Edn., IRRI, New York, ISBN-10: 0471879312, pp: 680.

Joy, P.P., 2010. Passion fruit production technology (Adhoc). Pineapple Research Station (Kerala Agriculture University) Vazhakulam-686670, Muvattupuzha, Ernakulm Dirstict, Kerala, India.

Kishore, K.A. Pathak, R. Shukla and R. Bharali, 2010. Studies on floral biology of passion fruit (Passiflora spp.). Pak. J. Bot., 42: 21-29.

Kole, C., 2011. Wild Crop Relatives: Genomic and Breeding Resources: Tropical and Subtropical Fruits. 1st Edn., Springer, ISBN-10: 3642204473, pp: 279.

Lambers, H., F.S. Chapin and T.L. Pons, 2008. Life cycles: Environmental influences and adaptations. Plant Physiol. Ecol. DOI: 10.1007/978-0-38778341-3_11

Madureira, H.C., T.N.S. Pereira, M.D. Cunha and D.E. Klein, 2012. Histological analysis of pollenpistil interactions in sour passion fruit plants (Passiflora edulis Sims). Biocell, 36: 83-90. PMID: 23185783

Matthews, M.L. and P.K. Endress, 2008. Comparative floral structure and systematics in chrysobalanaceae s.l. (Chrysobalanaceae, dichapetalaceae, Euphroniaceae, Trigoniaceae; Malpighiales). Bot. J. Linnean Soc., 157: 249-309. DOI: 10.1111/j.10958339.2008.00803.x

Patel, S.S., T.S.M. Saleem, V. Ravi, B. Shrestha and N.K. Verma et al., 2009. Passiflora incarnata Linn: A phytopharmacological review. Int. J. Green Pharm., 3: 277-80. 
Santos, E.A., M.M. Souza, A.P. Viana, A.F. Lmeida and I.S. Araujo, 2012. Development and bloom in hybrids of wild passion fruit cultivated in different types of pots and shading levels. Sci. Agric. DOI: 10.1590/S0103-90162012000200007

Shivanna, K.R., 2012. Reproductive assurance through unusual autogamy in the absence of pollinators in Passiflora edulis (passion fruit). Curr. Sci., 103: 1091-1096.

Silva, M.L.D., D.L.P. Pinto, M.P Guerra, E.I.S. Floh and C.H. Bruckner et al., 2009. A novel regeneration system for a wild passion fruit species (Passiflora cincinnata Mast.) based on somatic embryogenesis from mature zygotic embryos. Plant Cell Tiss Org. 99: 47-54. DOI: 10.1007/s11240-009-9574-2
Souza, M.M., A.P. Viana and T.N.S. Pereira, 2010. A putative mutant of a self-compatible yellow passion fruit with the corona color as a phenotypic marker. Bragantia. DOI: 10.1590/S00067052010000100003

Ullah, M.M., M.A. Rouf, A. Alam, C.K. Das and I. Ahmed, 2009. Modern Cultivation of Passion Fruit (In Bengali). 1st Edn., Hill Agricultural Research Station, BARI, Khagrachari. 